\title{
La suppression de décollements dans les chambres d'eau par l'emploi de guideaux de fond
}

\section{Aerodynamic guides used in novel forebay design}

\author{
PAR G. D. RANSFORD
}

INGÉNIEUR AU LaBoratotre DAUPHINOIS D'HYDRAULIQUe DE la SOGREAH, CRENOBLE

\begin{abstract}
Par l'adjonction de guideaux aérodynamiques à un chenal d'amenée il fut possible d'empècher une séparation de l'écoulement dans la chambre d'eant, à la fois courbe et divergente, servant $\dot{a}$ alimenter une centrale hydrom électrique. La disposition des guideanx fut déterminée par des essais sur modèle réduit; en se basant sur les résultats obtenus et grâce dà certaines formules déjà obtenues par d'autres chercheurs, l'auteur donne une analyse théorique rapprochée de l'action des guideaux.
\end{abstract}

\section{INTRODUCTION}

L'un des problèmes les plus difficiles de l'hydraulique semble être la prévention des décollements dans les canaux divergents, surtout si ceux-ci sont courbes.

L'importance pratique de cette question n'échappe à personne. En cas de décollement, la formation de grands rouleaux à axe vertical ne peut être évitée. Si, dans la zone tourbillonnaire, il se trouve une partie des grilles destinées à protéger une prise d'eau, la vitesse d'écoulement, et donc les pertes de charge, seront augmentées dans la partie restante des grilles. Même s'il n'en est pas ainsi, l'écoulement devant les grilles devient plus ou moins incliné par rapport à l'axe de la prise, les pertes de charge augmentent considérablement, et un second décollement peut se produire derrière les grilles, dans la bâche spirale. Il en résulte une modification de l'angle d'attaque du courant absorbé
By placing glides of aerodynamic shape in a head-race canal, it was possible to prevent a breakaway of flow in the curved, diverging section at the entrance to the forebay. The location of the guides was determined by scale model investigations; on the basis of the results obtained, and availing himself of certain formulae derived by other investigators, the author outlines an approximate method of analysis which may prove useful in future studies of this type.

\section{INTRODUCTION}

One of the most difficult problems confronting the hydraulic engineer is the prevention of flow separation from the sides of diverging canals, particularly in the case of curved alignments. The practical importance of this question is well known. When breakaway occurs, the formation of large eddies cannot be avoided. Part of the screens placed in front of an intake may lie in the eddy zone, in which case the velocity of flow-and thus the head losses-will be increased in the remaining part of the screens. Even if this is not the case, the direction of flow at the intake becomes more or less sharply inclined to the screens, the head losses are greatly increased and separation of the flow, for a second time, may take place behind the screens, i.e., from the scroll casing walls, and the ribs used for guiding the flow to the turbines. The result is to change the angle 
par les turbines et une baisse de rendement de ces dernières.

D'un autre côté, des dépôts de boue peuvent se former dans les zones d'eau morte créées par les décollements. On rencọtre souvent de tels dépôts dans les aménagements vétustes où une grosse partie de la capacité de chambre d'eau fournie à un prix élevé s'avère inutile.

Tandis que l'emploi des guideaux décrits ici ne peut, bien entendu, être considéré comme un remède universel susceptible de rẻsoudre tous les problèmes de cette espèce, il convient de noter les trois avantages suivants:

a) Les guideaux peuvent s'adapter à une grande variété de tracés de chenaux et de chambres de mise en charge;

b) Ils sont de petites dimensions et peuvent être choisis tous de la même forme dans une application quelconque;

c) Ils peuvent être conçus de manière à rendre insignifiante l'obstruction qu'ils créent.

Ces qualités sont d'un intérêt particulier lorsqu'il s'agit de rénover des aménagements vétustes.

Etant donné que la mise au point d'un système de guideaux requiert une étude approfondie, ainsi qu'il ressort des détails portés sur la figure 2, on comprend qu'un essai sur modèle réduit est nécessaire dans tous les cas.

La théorie que nous donnons plus loin ne prétend pas à une précision scientifique; il ne s'agit que de donner une idée approximative quant aux dimensions et à la disposition des guideaux. Les hypothèses que nous serons amenés à admettre sont d'ailleurs assez éloquentes à cet égard.

\section{LA GENĖSE DU PROCEDE}

L'étude sur modèle réduit d'un nouvel aménagement hydroélectrique au Congo Belge fut confié au Laboratoire Dauphinois d'Hydraulique, Grenoble, par le Maître de l'Euvre, la Société des Forces Hydroélectriques de I'Est de la Colonie, Bruxelles.

Le débit maximum de chacune des trois turbines sera de $40 \mathrm{~m}^{3} / \mathrm{s}$; en saison sèche, le fonctionnement des groupes aux heures de pointe conduira à un abaissement du niveau de la retenue jusqu'à la cote 437 , la retenue normale ćtant de 440 .

On fut contraint, en raison de la topographie du lieu, à décaler le bâtiment de la centrale par rapport à l'axe du canal d'amenée; par conséquent, la chambre d'eau est à la fois courbe et divergente (voir la fig. 1). Les essais de ce tracé primitif, sans guideaux, mirent en évidence un grand rouleau à axe vertical dans la chambre of flow entering the turbines and a loss of efficiency must result.

On the other hand, deposits of mud form in the regions of dead water created by the eddies. These deposits are in evidence in many of the older power schemes, where much of the volume provided at great cost in forebays has turned out to be ineffective.

While the use of the guides to be described in this article cannot be expected to provide a universal panacea for all problems of this nature, three particular advantages may be noted:

(1) The guides can be adapted to a wide variety of canal and forebay layouts;

(2) They are small and may all be made of the same shape in any particular application -hence they should always prove inexpensive;

(3) They may be designed and located so as to minimize the obstruction caused by them.

These features make them of particular interest for use in 'renovating' old power schemes.

As will be appreciated from the peculiarities of their layout, a model test is required in order to determine the most suilable arrangement in any particular case. The theory given below does not pretend to be anylhing more than an aid to the engineer engaged on model studies. It aims only at giving an idea of the general dimensions and layout of the guides, and is not a rigorous design method; this will be made evident by the assumptions used.

\section{THE GENESIS OF THE NEW DESIGN}

The model study of a new hydro-power scheme in the Belgian Congo was ordered from the Laboratoire Dauphinois d'Hydraulic, Grenoble, by the Constructing Authority, La Société des Forces Hydroélectriques de l'Est de la Colonie, of Brussels.

The maximum discharge of each of the three turbines to be installed will be $40 \mathrm{~m}^{3 /} / \mathrm{s}$, and, owing to pondage operation in the dry season, the reservoir level, normally maintained at R.L. 440 (metres), may be drawn down to R.L. 437 .

Topographical considerations made it necessary to offset the power house from the centreline of the head-race canal, and the forebay is therefore curved and diverging in plan (see fig. 1). When the original design, without guides, was tested out on the model, the 


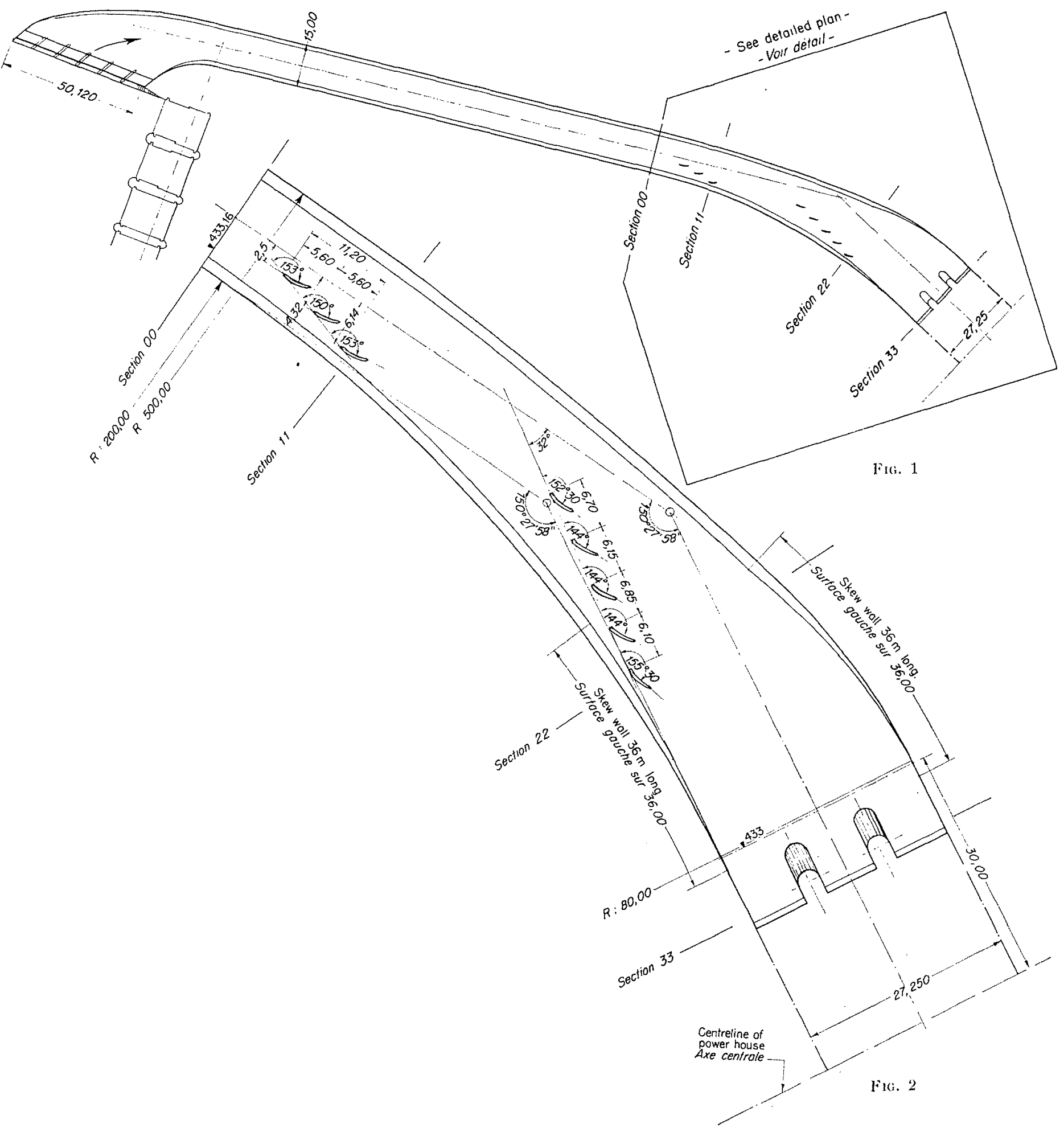

d'eau, près de la paroi convexe. Des injections d'encre de Chine rendirent d'ailleurs visibles les courants de retour le long de cette paroi (voir la fig. 3). Néanmoins, les essais effectués par la suite sur d'autres tracés (avec un fond latéralement incliné, par exemple), montrèrent que le existence of a large eddy was observed on the inner side of the curved forebay. Return currents along the convex wall of the forebay were made visible by injecting Indian ink at points on this wall (see fig. 3). Even so, tests conducted on other designs of forebay (e.g., with a sideways 
tracé primilif était peut-être plus satisfaisant que la plupart des variantes « classiques » qu'on pourrait trouver.

Cet échec nous conduisit alors à entreprendre des recherches sur des guideaux semblables à ceux décrits dans un article de A. A. Bolshakov. Dans cet article, il fut démontré que la création d'une circulation secondaire « artificielle » dans un chenal divergent à axe rectiligne empêchait le « décollement» de l'écoulement des parois; trois systèmes de circulation « artificielle 》 furent expérimentés, et les résultats obtenus s'avérèrent très prometteurs.

On a mis au point plusieurs sortes de guideaux; dans le cas présent, toutefois, l'emploi de panneaux fixés rigidement au fond du canal s'impose. Les guideaux doivent épouser un tracé aérodynamique, afin d'éviter des décollements du revers des guideaux; de même, il est peut-être préférable de prévoir un nombre un peu élevé de petits guideaux disposés en cascade plutôt que les guideaux moins nombreux, mais plus encombrants, qu'on emploie couramment dans d'autres applications des écoulements secondaires.

Dans notre application de cette idée à une chambre d'eau courbe, nous parvìnmes à la solution suivante : on admit que la circulation secondaire "naturelle» peut subsister dans une moitié du canal, tandis que, dans l'autre moitié, une circulation secondaire « artificielle » carac-

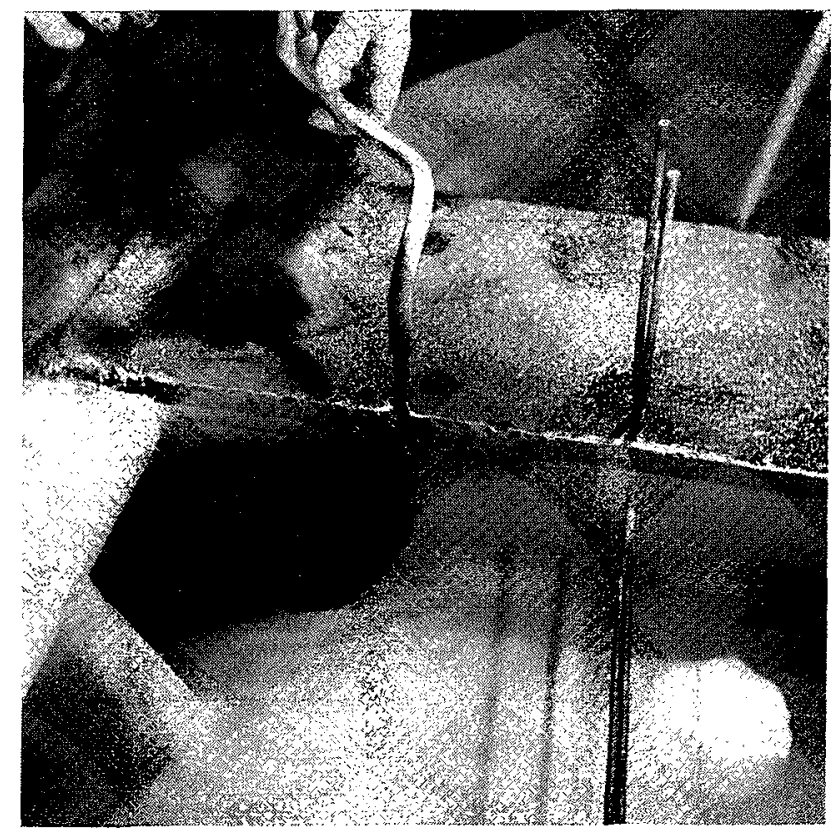

FIG. 3 sloping bottom) showed that the original design was less unsatisfactory than most of the conventional alternatives that could be suggested.

As a result of this failure to improve flow conditions in the forebay, it was decided to make tests on guides similar to those described in an article by A. A. Bolshakov in Vol. 30 of the Proceedings of the Вниигим for 1950. In this article it was shown that the creation of spiral flow in a straight, diverging channel hindered flow separation; three different types of spiral motion artificially induced by guide blades were tried out in a testing flume and the results were most promising.

Many different types of guides can be devised, but in cases such as the present the use of guides rigidly fixed to the canal bottom is indicated. They should moreover be streamlined so as to prevent flow separation from the backs of the guides; for the same reason, the use of a fairly considerable number of small guides arranged in cascades is to be preferred to the use of fewer, but longer and larger, guides as is desirable in other developments of guided, spiral flow.

In our own application of this idea to a curved forebay, it was considered that the natural spiral motion due to the bend could be allowed to subsist in one half of the canal, while. in the other half, an artificial spiral flow rotating in the opposite sense should be creating (see fig. 5). Bolshakov's tests showed that it would be desirable in fact to create a

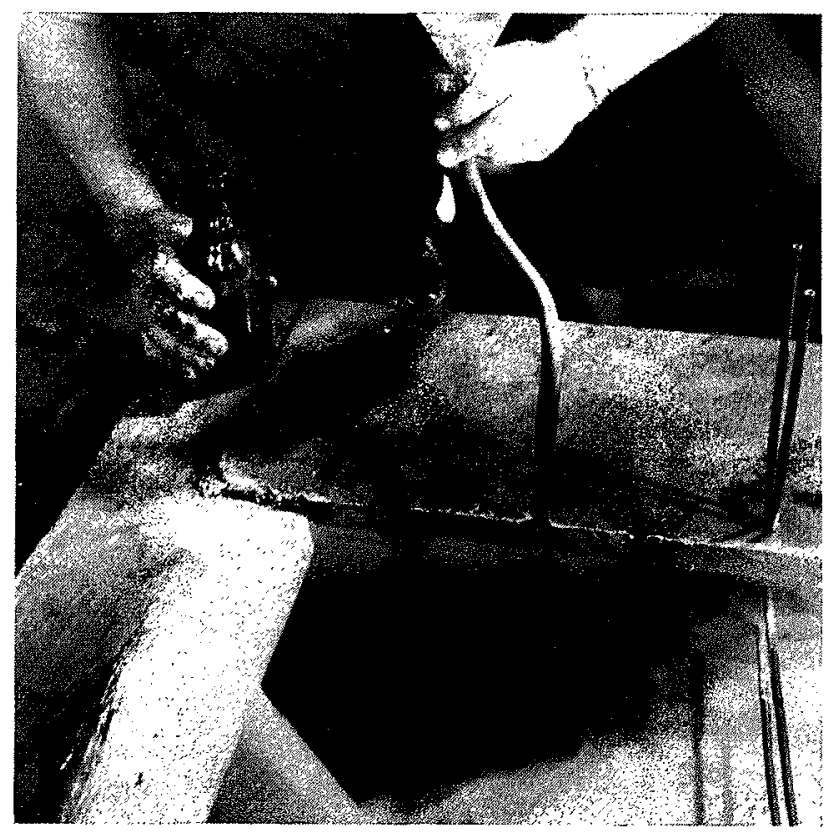

Fig. 4 
térisée par un sens de rotation conlraire devrail ètre engendrée (voir la fig. 5). Les essais de M. Bolshakov mirent en lumière, en effet, les avantages que comporte un mouvement en vrille double, les lignes de courant près du fond se dirigeant vers l'axe du canal et celles en surface, vers les berges.

Les mérites d'une telle disposition découlent des principes physiques qui sont à la base de l'effet stabilisateur des circulations secondaires. L'écoulement en vrille sert à remplacer des masses de liquide retardées sous l'influence des parois par des masses de liquide provenant du centre du chenal; dans le cas d'un écoulement en vrille double, le transfert s'effectue par les lignes de courant divergentes. Il est donc d'un meilleur rendement de prévoir des lignes de courant divergentes à la surface plutôt que sur le fond; comme l'indique la figure 6 , le temps requis pour un transfert de point $A$ (au centre du canal) à un point critique, tel que $B$, sur la paroi est nettement plus élevé, toutes choses étant égales par ailleurs, pour la trajectoire 1 que pour la trajectoire 2.

Ce raisonnement s'applique naturellement à des chenaux qui s'élargissent sans approfondissement notable; les conclusions seraient inversées dans le cas, assez invraisemblable dans la pratique, d'un chenal qui s'approfondirait sans élargissement.

La figure 2 montre la disposition détaillée des guideaux, disposition qui résulte des essais sur le modèle réduit; on voit également sur la figure 7 une vue générale du modèle avec les guideaux en place, et sur la figure 4 une vue de l'éconlement près de la berge convexe où, auparavant (fig. 3) existait un courant de retour.

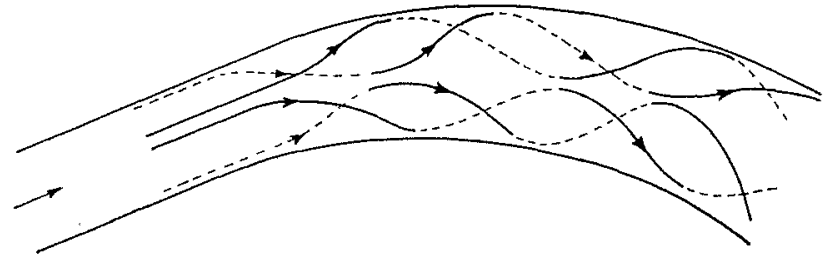

FIG. 5

Soulignons que la chambre d'eau mise au point par l'adjonction des guideaux, fonctionne de manière très satisfaisante, sans décollement:

- pour des cotes du plan d'eau comprises entre 437 et 440 , c'est-à-dire pour des profondeurs d'écoulement variant de 4 à $7 \mathrm{~m}$ environ;

- pour tous les modes d'exploitation possibles des turbines (avec une, deux ou trois de celles-ci en fonctionnement) et pour tous les débits que peuvent absorber les groupes. double spiral flow in which the bollom streamlines are directed inwards towards the centreline of the canal, the surface streamlines being divergent. The merit of the arrangement can be gauged from the physical principles involved in the flow-stabilizing effect of spiral flow. The spiral motion serves to replace masses of liquid slowed down under the effect of boundary friction by fresh, faster-moving liquid coming in from the centre of the channel along the diverging streamlines, in the case of double "corkscrew" flow. It is obviously more efficient to have the diverging streamlines at the surface than on the bottom-as will be seen from figure 6 , the distance required for bringing new fluid from the centre of the channel (point A) to a critical point such as $B$ on the side wall is much greater in the case of trajectory 1 (diverging bottom currenls) than in the case of trajectory 2 (diverging surface currents). Thus in the second case the retarded flow will be replaced much more rapidly-and by liquid which spends on the whole a very much shorter time near the solid boudaries in its passage.

This reasoning applies naturally to channels which widen without deepening very much; the conclusions would be reversed were breakaway to be feared from the bottom of a canal where the depth of flow increases without widening-a rather hypothetical problem.

Figure 2 shows the detailed layout of the guides as determined by the model tests; see figure 7 for a view of the model with the guides installed, and figure 4 for a view of the flow along the convex wall where previously (fig. 3) there was a back current.

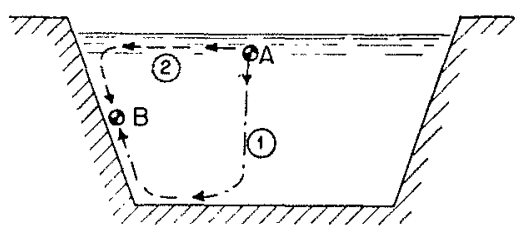

FIG. 6

It should be stressed that the forchay as finally designed with the addition of guides functions excellently, without flow separation,

(i) for levels ranging from 437 to 440 , i.c., for depths of flow varying from approximately 4 to 7 metres;

(ii) for all possible flow combinations, i.e., with one, two or three turbines in operation, and for all discharges within the rated capacity of the units. 
Il faul de même souligner que l'écoulement secondaire peut être considéré comme sans effet sur les pertes de charge aux grilles et sur les rendements des groupes par comparaison avec ceux qui existeraient en écoulement plan sans décollement. Les guideaux ont pour effet d'uniformiser la répartition des vitesses longitudinales à l'entrée des grilles; les vitesses transversales demeurent, en général, très faibles et sont sujettes à un amortissement assez rapide, donc l'effet de ces dernières sur les pertes de charge aux grilles - et, $\dot{a}$ fortiori, sur les rendements des groupes - doit être insignifiant. Il y a, bien entendu, les meilleures raisons pour que la rangée aval des guideaux soit reportée aussi loin en amont de la centrale que possible, afin de faire jouer l'amortissement inévitable de l'écoulement secondaire.

Il convient de remarquer enfin (en anticipant sur les résultats obtenus ultérieurement) que l'on peut justifier théoriquement l'efficacité persistante d'un jeu donné de guideaux, dans une large gamme de hauteurs d'eau.

\section{ANALYSE THEORIQUE DE L'ECOULEMENT}

Dans ce qui suit, nous donnerons une analyse approchée du développement de la vorticité :

- dans des canaux courbes à section carrée (sans guideaux);

- dans des canaux courbes et divergents (sans guideaux);

- dans des canaux à section constante et à axe rectiligne (avec une circulation transversale provoquée par des guideaux);

- dans des canaux divergents à axe rectiligne (avec guideaux);

- dans des canaux divergents à axe courbe (avec guideaux).

Nous ferons une application numérique des résultats obtenus à la chambre d'eau dont il a déjà été question. En conclusion, nous examinerons le problème général de la mise au point de ces systèmes de guideaux.

\section{SYMBOLES}

\section{Scalaires et composantes Vectorielles}

$b=$ largeur d'un chenal à section rectangulaire,

$b_{1}=$ largeur d'un chenal rectangulaire au début d'un divergent,

$f=\frac{b_{2}-b_{1}}{x_{2}-x_{1}}$, degré de divergence d'un canal,
It should be emphasized that the spiral flow set up in the forebay is practically without effect on the screen losses or the turbine efficiencies as compared with those to be expected in non-rotational, non-separating flow. The effect of the guides is to ensure a very uniform distribution of forward velocities at the screens; the transversal velocity components are on the average very small and are subject to fairly rapid damping out, so that the effect of these velocity components on the screen losses, and a fortiori, on the turbine efficiencies, should be insignificant. There is, of course, every reason for placing the rearmost cascade of guides as far away from the screens as is compatible with non-separation, so as to benefit from the damping of the "artificial" spiral flow that inevitably occurs.

It should be observed (in anticipation of results to be obtained subsequently) that there is theoretical justification for the sustained efficiency of a given set of guides over a wide range of flow depths.

\section{THEORETICAL ANALYSIS OF THE FLOW}

In the following pages we will give an approximate analysis of the development of vorticity :

a) in curved, constant-section channels (without guides);

b) in curved, diverging channels (without guides);

c) in straight, constant-section channels (with spiral flow induced by guides);

d) in straight, diverging channels (with spiral flow induced by guides);

$e$ ) in curved, diverging channels (with induced spiral flow).

A numerical application of the formulae obtained in $\S b$ and $\S e$ will be made to the case under consideration, and extension to the general design problem will be discussed.

\section{SYMBOLS}

\section{a) SCALARS AND VECTOR COMPONENTS}

$b=$ width of a rectangular canal,

$b_{1}=$ width of a rectanglar canal before diverging,

$f=\frac{b_{2}-b_{1}}{x_{2}-x_{1}}$, the rate of divergence of a canal, 
$h=$ profondeur l'écoulement,

$h^{\star}=$ hauteur des guideaux de fond,

$$
k=\frac{2 b h}{\sqrt{b^{2}+h^{2}}},
$$

$m, n, p=$ coordonnées scalaires correspondant aux axes définis par les vecteur's $\mathbf{m}, \mathbf{n}, \boldsymbol{p}$,

$I^{n}=$ rayon de courbure de l'axe d'un canal,

$s=r \theta$,

$u=$ composante de vitesse suivant l'axe des $x$ ou des $s$.

$u_{0}=$ vitesse " de fond $\gg$,

$u_{h}=$ vitesse en surface,

$\vec{u}=$ valeur moyenne de $u$,

$v, w=$ composantes de vitesse dans un plan perpendiculaire à $u$,

$v^{*}=$ valeur max. de $v$ dans une section,

$v_{c}=$ racine carrée de la moyenne de $\left(v^{2}+1 v^{2}\right)$ dans une section,

$x, y, z=$ coordomnées rectangulaires,

$\mathrm{C}=$ Coefficieni de Chézy,

$E=\frac{V^{2}}{2}+U+\frac{P}{P}$

$\mathbf{P}=$ pression,

$\mathrm{Q}=$ llébit,

$R=$ rayon hydraulique,

$\mathrm{U}=$ fonction de potentiel pour les forces extérieures,

$\mathrm{V}=\sqrt{u^{2}+v^{2}+w^{2}}$

$\alpha=$ angle de rotation des lignes de courant en parcourant un coude; $\alpha=0$ au début du coude,

$\beta=\frac{u_{h}-u_{0}}{u}$,

$\gamma=$ coefficient d'amortissement (en canal $\dot{a}$ section constante),

$\gamma^{*}=$ coefficient d'aunortissement, en canal divergent,

$0=$ coordonnée angulaire,

$y=$ viscosité cinématique,

$v^{*}=$ viscosité cinématique équivalente en amortissement turbulent,

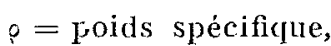

$p=$ angie de fuite des guideaux (angle apparenf de déviation),

$\stackrel{S}{m}_{m}=$ angle de déviation réel,

(1) = composante de rorticité selon $x$ ou $s$,

$\omega_{n}=$ composante de vorticité selon $\mathbf{n}$,

$\omega_{p}=$ composante de vorticité selon $\boldsymbol{p}$,

$\bar{\omega}=$ valeur moyenne de $\omega$. $h=$ depth of flow,

$h^{*}=$ height of guides,

$k=\frac{2 b h}{\sqrt{b^{2}+h^{2}}}$,

$m, n, p=$ scalar coordinates corresponding to axes defined by vectors $\mathbf{m}, \mathbf{n}, \boldsymbol{p}$,

$r=$ radius of curvature of canal axis,

$s=r 0$, arc length,

$u=$ velocity compontnt in $x$ - or $s$-direction,

$u_{0}=$ "bottom" velocity,

$u_{h}=$ surface velocity,

$\bar{u}=$ mean value of $u$,

$v, w=$ velocity components perpendicular to $u$,

$v^{*}=$ maximum value of $v$ at a given section,

$v_{c}=$ root mean square of $\sqrt{v^{2}+w^{2}}$ over a cross-section,

$x, y, z=$ Cartesian coordinates,

$\mathrm{C}=$ coefficient of Chézy:

$\mathrm{E}=\frac{\mathrm{V}^{2}}{2}+\mathrm{U}+\frac{\mathrm{P}}{\rho}$

$P=$ pressure,

$Q=$ discharge,

$\mathrm{R}=$ hydraulic radius,

$\mathrm{U}=$ potential function of external forces,

$\mathrm{V}=\sqrt{u^{2}+v^{2}+w^{2}}$

$\alpha=$ angle of rotation of streamlines in frictionless flow (with non-uniform velocity distribution) round a bend; $\alpha=0$ at the start of the bend,

$\beta=\frac{u_{h}-u_{0}}{u}$,

$\varphi=$ damping coefficient in a constant-section canal,

$\gamma^{*}=$ damping coefficient in a diverging canal,

$0=$ angular coordinate,

$v=$ kinematic viscosity,

$\nu^{*}=$ equivalent kinematic viscosity for turbulent damping,

$\rho=$ density,

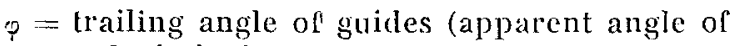
deviation),

$o_{n}=$ real angle of deviation of current,

$\omega=$ vorticity component in $x$-or s-direction,

$\omega_{n}=$ vorticity component in $\mathbf{n}$ direction,

$\omega_{p}=$ vorticity component in $\boldsymbol{p}$ direction,

$\bar{\omega}=$ mean value of $(\omega)$ over a cross section. 


\section{Vecteurs}

$\mathbf{m}=$ vecteur unitaire perpendiculaire à $\mathbf{n}, \boldsymbol{p}$,

$\mathbf{n}=$ vecteur unitaire perpendiculaire à $\boldsymbol{p}$, dans un plan contenant le vecteur de vorticité,

$\boldsymbol{p}=$ vecteur unitaire dirigé dans le sens de $\mathbf{v}$,

$\mathbf{F}=$ force externe agissant sur une masse unitaire de fluide,

$\mathbf{v}=$ vecteur de vitesse,

$\mathbf{\Omega}=(\nabla \times \mathbf{v})$, la vorticité.

A) ANalyse de L'ÉCOULEMENT DANS DES ChENAUX COURBES A SECTION CARRÉE (SANS GUIDEAUX).

$1^{\circ}$ En premier lieu nous étudierons l'accroissement de la vorticité dans un liquide caractérisé par une répartition de vitesses non uniforme. L'analyse qui fut donnée pour la première fois par le professeur W. R. HawrHoRnE (voir R. E. Kronauer, « Secondary Flows in Fluid Dynamics »- Thèse du Massachusetts Institute of Technology, 1951), est basée sur une extension du théorème de HesmHoltz concernant la vorticité d'un fluide en écoulement permanent, théorème dont la preuve suit.

En termes vectoriels, l'équation de mouvement d'un liquide non visqueux s'écrit :

\section{b) Vectors}

$$
\begin{aligned}
& \mathbf{m}=\text { unit vector perpendicular to } \mathbf{n}, \mathbf{p}, \\
& \boldsymbol{n}=\text { unit vector perpendicular to } \boldsymbol{p} \text {, in a plane } \\
& \boldsymbol{p}=\text { unit vector in direction of } \mathbf{v} \text { at each point, } \\
& \boldsymbol{F}=\text { external force acting on unit mass of a } \\
& \mathbf{v}=\text { vector velocity, } \\
& \mathbf{\Omega}=(\nabla \times \mathbf{v}) \text {, the vector vorticity, }
\end{aligned}
$$

\section{(A) ANALysis of Flow In CuRVED, APpRoximately SQUARE CHANNELS WITHOUT GUIDES.}

(i) The first part of this analysis is concerned with the evaluation of the rate of change of vorticity in an inviscid liquid with a non-uniform velocity distribution. The analysis, which was first given by Professor W. R. Hawthorne (see R. E. Kronauen : "Secondary Flows in Fluid Dynamics", M.I.T. Thesis, 1951), is based on a development of HesmholTz's theorem on the rate of change of vorticity (in the case of steady flow of an inviscid liquid); this theorem will first be proved.

In vector from, the equation of motion of an inviscid liquid may be written :

$$
\frac{\partial \mathbf{v}}{\partial t}+\nabla\left(\frac{\mathrm{V}^{2}}{2}\right)+(\nabla \times \mathbf{v}) \times \mathbf{v}=\mathbf{r}-\frac{1}{?} \nabla \mathbf{P}
$$

Nous supposerons que les forces extérieures possèdent une fonction de potentiel, $\mathrm{F}=-\nabla \mathrm{U}$. Nous pouvons donc écrire :
Supposing that the external forces are conservative, with $\mathbf{F}=-\nabla \mathbf{U}$ :

$$
\frac{\partial \mathbf{v}}{\partial t}+\mathbf{\Omega} \times \mathbf{v}=-\nabla\left(\frac{\mathrm{V}^{2}}{2}+\mathrm{U}+\frac{\mathrm{P}}{\rho}\right)
$$

Si l'on prend le rotationnel des deux membres de cette équation, en se rappelant que le rotationnel d'un gradient est nul, nous obtenons :
Taking the curl of both sides, and remembering that the curl of a gradient is identically zero, we have :

$$
\frac{\partial \boldsymbol{\Omega}}{\partial t}+\nabla \times(\mathbf{\Omega} \times \mathbf{v})=0
$$

Les formules d'expansion pour les produits vectoriels donnent :

The formulae of expansion for vector products give :

$$
\frac{\partial \boldsymbol{\Omega}}{\partial t}+(\mathbf{v} \cdot \nabla) \mathbf{\Omega}=(\boldsymbol{\Omega} \cdot \nabla) \mathbf{v}-\boldsymbol{\Omega}(\nabla \cdot \mathbf{v})
$$

Pour un écoulement permanent, le premier lerme s'annule; le dernier s'annule également en vertu de l'équation de continuité :
For the steady case, the first term drops out; the last drops out on account of the continuity condition :

$$
\nabla \cdot \mathbf{v}=0
$$


Le théorème de Helmholtz s'écrit alors sous la forme :
The simplified form of HeLmholtz's theorem is then obtained :

$$
(\mathbf{v} \cdot \nabla) \boldsymbol{\Omega}=(\boldsymbol{\Omega} \cdot \nabla) \mathbf{v}
$$

L'analyse de M. KronaUer (suivant une suggestion de Von Mises) procède comme suit :

Le développement de (1) fournit l'équation :

KronaUER's analysis (based on a suggestion of the late Professor R. von Mises) then proceeds as follows.

Expanding the foregoing :

$$
\mathrm{V} \underset{\partial p}{\partial}\left\{\omega_{p} \mathbf{p}+\omega_{n} \mathbf{n}\right\}=\omega_{p} \frac{\partial \mathbf{v}}{\partial p}+\omega_{n} \frac{\partial \mathbf{v}}{\partial n}
$$

ou encore :

or :

$$
\mathrm{V}\left\{\frac{\partial \omega_{p}}{\partial p} \boldsymbol{p}+\frac{\partial \omega_{p}}{\partial p} \boldsymbol{n}\right\}=\omega_{p}\left\{\frac{\partial \mathrm{V}}{\partial p} \boldsymbol{p}\right\}+\omega_{n}\left\{\frac{\partial \mathrm{V}}{\partial \boldsymbol{n}} \boldsymbol{p}+\mathrm{V} \frac{\partial \boldsymbol{p}}{\partial \boldsymbol{n}}-\mathrm{V} \frac{\partial \boldsymbol{n}}{\partial p}\right\}
$$

Le produit scalaire avec $\boldsymbol{p}$ donne :

The scalar product with $\boldsymbol{p}$ gives :

$$
\mathrm{V} \frac{\partial \omega_{p}}{\partial p}=\omega_{p} \frac{\partial \mathrm{V}}{\partial p}+\omega_{n} \frac{\partial \mathrm{V}}{\partial \boldsymbol{n}}-\omega_{n} \mathrm{~V} \frac{\partial \mathbf{n}}{\partial p} \cdot \boldsymbol{p}
$$

D'autre part :

\section{Now :}

$$
\frac{\partial \mathbf{v}}{\partial n}=\frac{\partial \mathbf{V}}{\partial n} \boldsymbol{p}+\mathrm{V} \frac{\partial \boldsymbol{p}}{\partial n}
$$

et :

$$
\frac{\partial \mathbf{v}}{\partial p}=\frac{\partial \mathbf{V}}{\partial p} \mathbf{p}+\mathrm{V} \frac{\partial \boldsymbol{p}}{\partial p}
$$

Il s'ensuit que, en particulier :

So that, in particular :

$$
\left(\frac{\partial \mathbf{v}}{\partial n}\right)_{p}=\frac{\partial \mathbf{v}}{\partial n} \cdot \boldsymbol{p}=\frac{\partial \mathrm{V}}{\partial n}
$$

et :

$$
\text { and : }
$$

$$
\left(\frac{\partial \mathbf{v}}{\partial p}\right)_{n}=\frac{\partial \mathbf{v}}{\partial p} \cdot \mathbf{n}=\mathrm{V}\left(\frac{\partial \mathbf{p}}{\partial p} \cdot \mathbf{n}\right)
$$

Or :

Now :

$$
\omega_{m} \equiv 0
$$

Done : so that :

$$
-\omega_{m}=-\left(\frac{\partial \mathbf{v}}{\partial n}\right)_{n}+\left(\frac{\partial \mathbf{v}}{\partial p}\right)_{n}=0
$$

En se souvenant que :

Remembering that :

$$
\frac{\partial \boldsymbol{n}}{\partial \boldsymbol{p}} \cdot \mathbf{p}=-\frac{\partial \boldsymbol{p}}{\partial p} \cdot \mathbf{n}
$$

on obtient, d'après (7) et (9), que :

we have, using successively (7) and (9):

$$
\omega_{n} \frac{\partial \mathrm{V}}{\partial n}=\omega_{n}\left(\frac{\partial \mathbf{V}}{\partial n}\right)_{p}=\omega_{n}\left(\frac{\partial \mathbf{V}}{\partial p}\right)_{n}
$$

et d'après (10) et (8) que :

and, using (10) and (8) :

$$
-\omega_{n} \mathrm{~V} \frac{\partial \boldsymbol{n}}{\partial p} \cdot \mathbf{p}=\omega_{n} \mathrm{~V} \frac{\partial \boldsymbol{p}}{\partial p} \cdot \boldsymbol{n}=\omega_{n}\left(\frac{\partial \mathbf{V}}{\partial p}\right)_{n}
$$


Par conséquent, à l'aide des équations (11) et (12), l'équation (4) peut s'écrire :

$$
\mathrm{V} \frac{\partial \omega_{p}}{\partial p}=\omega_{p} \frac{\partial \mathrm{V}}{\partial p}+2 \omega_{n}\left(\frac{\partial \mathbf{V}}{\partial p}\right)_{n}
$$

Il s'ensuit que :

It follows that :

$$
\mathrm{V}^{2} \frac{\partial}{\partial p}\left(\frac{\omega_{p}}{\mathrm{~V}}\right)=2 \omega_{n}\left(\frac{\partial \mathbf{v}}{\partial p}\right)_{n}
$$

ou encore que :

or :

$$
\frac{\partial}{\partial p}\left(\frac{\omega_{p}}{\mathrm{~V}}\right)=\frac{2 \omega_{n}}{\mathrm{~V}^{2}}\left(\frac{\partial \mathbf{v}}{\partial p}\right)_{n}
$$

Comme M. Kronauer le fait remarquer, les dérivées partielles par rapport à $p$ sont des dérivées totales dans le sens habituel de l'hydrodynamique : l'équation (13) s'écrira done :
As Kronauer points out, partial derivatives with respect to $p$ are total derivatives in the usual sense of fluid mechanics, so that (13) may be written :

$$
\frac{d}{d p}\left(\frac{\omega_{p}}{\mathrm{~V}}\right)=\frac{2 \omega_{n}}{\mathrm{~V}^{2}}\left(\frac{d \mathbf{V}}{d p}\right)_{n}
$$

Cette équation donne le taux d'accroissement de la composante de la vorticité selon $p$ en fonction de la vitesse d'écoulement. Une expression semblable pour $\omega_{n}$ peut être établie.

$2^{\circ}$ La seconde partie de l'analyse porte sur l'évaluation de l'accroissement de la composante de vorticité $\omega$ dans des chenaux courbes à section carrée. Cette étude, que nous devons au professeur W. R. Hawthorne et à M. Joy (voir Joy : « Experimental Investigation of Shear Flow in Rectangular Bend's 》- Thèse M.I.T., 1950) est basée sur l'équation (14). Les hypothèses employées sont les suivantes :

a) Nous remplacerons $p$ par $s$ et $\omega_{p}$ par $\omega$; en d'autres termes, on suppose que la circulation transversale est faible par rapport à l'écoulement longitudinal principal;

b) La vitesse $V$ sera remplacée par la « vitesse axiale moyenne $\gg \bar{u}$;

c) Une section carrée $b \times b$ sera assimilée au cercle inscrit de diamètre $b$. Les essais de M. Kronaver valident cette hypothèse.

Il s'ensuit que, ici, $h=b$;

d) On admettra que la répartition initiale des vitesses longitudinales est linéaire et que, initialement, les isotaches sont horizontales. Cette hypothèse, malgré sa manifeste inexactitude, se justifie par l'emploi que nous en ferons; il s'agit en réalité d'évaluer la vorticité $\omega_{n}$ au début du coude, et suivant notre hypothèse, celle-ci est constante sur toute la section mouillée et égale à :
This equation gives the rate of change of the vorticity component in the $p$ direction as a function of the velocity. A similar equation giving the rate of change of $\omega_{n}$ can also be found.

(ii) The second part of the analysis is concerned with the approximate analysis of the increase in the vorticity component $\omega$ in curved channels of square section. The analysis, which follows that of Professor W. R. HAw'THORNE and W. Joy (see Joy : "Experimental Investigation of Shear Flow in Rectangular Bends", M.I.T. Thesis, 1950) is based on equation (14), as will be explained :

a) We replace $p$ by $s$ and $\omega_{p}$ by $\omega$, i.e., it is supposed that the secondary flow is small as compared to the main, axial flow;

b) The velocity $\mathrm{V}$ will be replaced by the ' mean forward velocity ', $\bar{u}$;

c) A square cross-section of side $b$ will be assimilated, for the evaluation of the rate of twisting of the streamlines, to the inscribed circle of diameter $b$. Kronauen's tests support this assumption.

$$
\text { Here, } h=b \text {. }
$$

d) We suppose that the initial velocity distribution is linear, lines of equal velocity being horizontal. Despite its seeming inexactitude, this assumption can be justified by the use made of it; our aim is to evaluate $\omega_{n}$ at the start of the bend, and according to this hypothesis, $\omega_{l}$ is constant over the whole cross-section and equal to :

$$
\frac{u_{h}-u_{0}}{h}=\frac{\beta \pi}{b}
$$


e) On supposera que $\omega$ reste constant sur toute la section mouillée, malgré les petite variations de V, lesquelles, selon (14), conduisent à des taux d'accroissement de $\omega$ légèrement différents à mesure qu'on parcourt le coude. Nous écrirons donc : e) It will be supposed that $\omega$ remains constant over the cross-section of flow, despite the slight variations in $\mathrm{V}$ which, according to (14), lead to slightly different rates of increase in $\omega$ as the flow passes round the bend. We may therefore write :

$\omega=\bar{\omega}$

f) Sauf dans la mesure où elle contribue à l'existence de la répartition de vitesses primitive, la rugosité des parois ne sera pas prise en considération. La théorie s'applique à des coudes qui ne sont pas « trop longs 》.

L'équation (14) peut s'écrire sous la forme : f) Wall friction, except inasmuch as it contributes to the original, non-uniform velocity distribution, will be neglected.

Equation (14) may be written :

$$
\frac{d}{d s}\left(\frac{\bar{\omega}}{\bar{u}}\right)^{2}=-\frac{2 \beta}{b} \cos \alpha \frac{d \theta}{d s}
$$

On notera que $-\bar{u} \cos \alpha(d \theta / d s)$ représente la composante selon $n$ du gradient des vitesses vectorielles, dans l'hypothèse que les lignes de courant et les isotaches subissent une rotation a « en bloc », l'angle de rotation du coude étant de $\theta$ et vers la droite (voir la fig. 7).

Il s'ensuit que :
Note that $-\bar{u} \cos \alpha\left(d \theta_{j}^{\prime} d s\right)$ represents the $n-$ component of the vector velocity gradient, on the supposition that the streamlines (and the contours of equal velocity) rotate without distorting through an angle $\alpha$ while the bend curves to the right with positive $\theta$ (see fig. 7 ).

It follows that :

$$
\bar{\omega}=-\frac{2 \beta \bar{u}}{b} \int_{0}^{0} \cos \alpha d \theta
$$

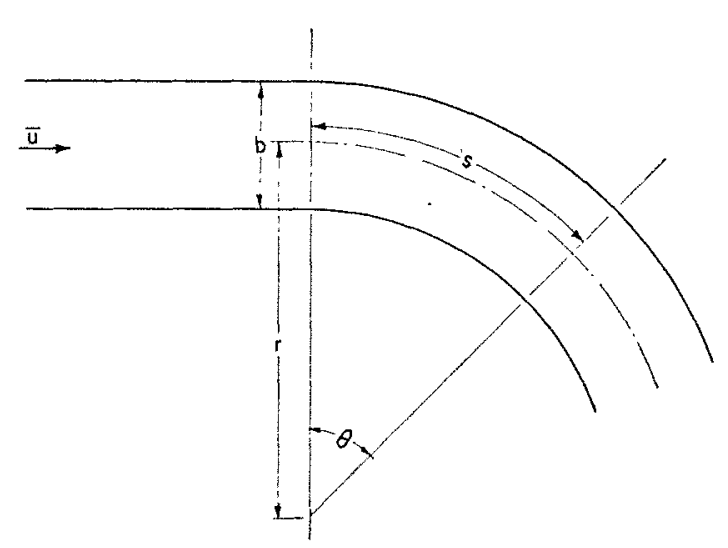

Fig. 7

Le signe moins indique que les lignes de courant commencent à tourner dans un sens opposé à celui de la rotation des aiguilles d'une montre, si $\beta$ est positif (c'est toujours le cas dans les chenaux à ciel ouvert).

Compte tenu de la définition de $\bar{\omega}$, nous trouvons que, sur la circonférence du cercle de diamètre $b$ :
The negative sign indicates that the streamlines start rotating in a counterclockwise direction in a bend turning to the right, if $\beta$ is positive (as is always the case in open channels).

From the definition of $\bar{\omega}$, on the outer circumference of the inscribed circle, we find, in the case we are considering, that:

$$
\sqrt{v^{2}+w^{2}}=-\bar{\omega} \frac{b}{4}
$$


Mais :

But :

$$
\sqrt{v^{2}+w^{2}}=\frac{b}{2} \frac{d \alpha}{d t}
$$

D'autre part, pour $\mathrm{R}$ suffisamment grand, on peut écrire approximativement : $\bar{u}=\mathrm{R}(d \theta / d t)$.

Also $\bar{u}=\mathbf{R}(d \theta / d t)$ approximately, for large $\mathbf{R}$.

Il en résulte que, avec une bonne approximation :

It follows that, approximately :

$$
\frac{d \alpha}{d \theta}=-\frac{\mathrm{R} \omega}{2 \bar{u}}=\frac{\beta \mathrm{R}}{b} \int_{0}^{\theta} \cos \alpha d \theta
$$

Après différentiation et intégration, on obtient l'expression suivante pour $\theta$ :

A simple differentiation and integration gives :

$$
\theta=\sqrt{\frac{b}{2 \beta R}} \int_{0}^{a} \frac{d \alpha}{\sqrt{\sin \alpha}}
$$

$3^{\circ}$ Nous pouvons maintenant évaluer $\alpha$ d'après (17) avec des intégrales elliptiques. Il vient : (iii) This last equation (17) can be evaluated in terms of elliptic integrals of the lemniscate type. We find :

$$
\operatorname{tg} \frac{\alpha}{2}=\frac{1-\operatorname{cn}[\theta \vee \overline{(b / \beta R})]}{1+\operatorname{cn}[\theta \sqrt{(b / \beta R})]}
$$

avec le paramètre $m=(1 / 2)$ pour la fonction cn.

Pour les problèmes dont nous nous occupons ici, où l'argument de la fonction $c n$ ne dépassera probablement pas l'unité, les premiers termes de la série (valable pour $m=[1 / 2]$ ): with the parameter $m=1 / 2$ for the function $\mathrm{cn}$.

For the problem dealt with here, where the argument of the en function is not likely to exceed unity, the series approximation (for $m=1 / 2$ ).

$$
\text { cn } u=1-\frac{u^{2}}{2}+\frac{u^{4}}{8}-\frac{3 u^{6}}{80}+
$$

pourront fort bien convenir.

Done : is likely to prove adequate.

Thus :

$$
\operatorname{tg} \frac{\alpha}{2}=\frac{b}{10 \beta R} \theta^{2}\left\{\frac{80-10(b / \beta R) \theta^{2}+3\left[(b / \beta R) \theta^{2}\right]^{2}+\ldots}{16-4(b / \beta R) \theta^{2}+\left[(b / \beta R) \theta^{2}\right]^{2}+\ldots}\right\}
$$

Cette façon d'exprimer le résultat fondamental de la théorie cache la périodicité de la solution exacte, périodicité qu'on observe d'ailleurs dans des tuyaux fortement coudés (HAwTHORNE, JoY); $\alpha$ atteint un maximum pour diminuer ensuite. Il ne sera toutefois pas question de ce phénomène ici.

La formule requise pour nos besoins ultérieurs est celle qui donne $\bar{\omega}$. Si l'on prend l'expression (20), l'intégrale de (15) peut s'exprimer :
This way of writing the basic result of the theory cloaks the periodicity of the solution actually observed in sharp pipe bends (HAwTHORNE, JOY) where the rotation $\alpha$ of the streamlines attains a maximum and then diminishes.

The important formula for future use is the one giving $\varpi$. Substitution of (20) in (15) and integration to the same order of accuracy as in (20) give the expression :

$$
\bar{\omega}=-\frac{2 \beta \bar{u}}{b}\left\{\theta-\left(\frac{b}{\beta \mathrm{R}}\right)^{2} \frac{0^{5}}{40}\right\}
$$


A très peu de chose près, dans la gamme de valeurs de $\theta$ qui nous intéresse : or, practically speaking, within the limits of 0 considered here :

$$
\bar{\omega}=-\frac{2 \beta \bar{u}}{b} \theta
$$

Une formule analogue fut établie par Jox, par une autre méthode d'analyse. Si l'on compare (21) et (15), on voit que $\approx$ reste forcément petit sur un certain parcours du coude; ce résultat n'était pas évident à priori.

\section{B) Analyse de l'écoulement dans les chenaux COURBES ET DIVERGENTS (SANS GUIDES).}

La principale difficulté ici (pourvu qu'aucun décollement ne se produise) semblerait provenir de ce que la section en travers s'écarte plus ou moins de la forme carrée. Toutefois, dans la gamme de courbures étudiées ici, nous pouvons prendre :
An equivalent formula was found by Joy by a different approach. Comparing with (15), we see that $\alpha$ must remain very small for some distance around the bend; this, however, was not evident at first sight.

(B) Analysis of flow in curved, diverging CILANNELS WITHOUT GUIDES.

The main difficulty here, provided that breakaway does not occur, would seem to lie in the departure from a square, or approximately square, section. However, in the range of curvature of prime interest here, we may take :

$$
\cos \alpha=1
$$

La dérivée de l'équation (21) :

The derivative of equation (21):

$$
\frac{d \bar{\omega}}{d \theta}=-\frac{2 \beta \bar{u}}{h}
$$

est valable en chaque section du chenal divergent, quelle que soit la forme exacte de cette section. En admettant, comme auparavant, que les isotaches sont primitivement parallèles au fond, nous obtenons : holds at each point in the curved, diverging channel, irrespective of the exact shape of the section: on the supposition, as before, that contours of equal velocity are initially parallel to the bottom:

$$
\bar{\omega}=-\frac{2 \beta}{h} \int_{0}^{\theta} \bar{u} d 0
$$

\section{C) Analyse de l'écoulement secondaire chéé DANS UN CHENAL A SECTION CONSTANTE PAR DES GUIDEAUX.}

L'analyse suivante est basée sur les travaux de Bolshakov et de ses collaborateurs, comme il a déjà été mentionné.

Des essais ont montré que la répartition de vitesses caractérisant une circulation transversale simple ayant le même sens de rotation que les aiguilles d'une montre était donnée, dans un chenal rectangulaire, par les formules suivantes (voir Ja fig. 8) :
(C) Analysis of spiral flow in straight consTANT-SECTION CHANNELS WITH GUIDES.

The following analysis is based on the work of Bolshakov (and his associates), as mentioned previously.

Tests have shown that the velocity distribution in a rectangular channel with a single, clockwise-rotating secondary circulation is given quite accurately by the following formulae (see fig. 8) :

$$
\begin{aligned}
& u=\bar{u}=\mathrm{C}^{\mathrm{te}} . \\
& v=\frac{k}{h} v_{c} \cos \frac{\pi y}{b} \sin \frac{\pi z}{h} \\
& w=-\frac{k}{b} v_{c} \sin \frac{\pi y}{b} \cos \frac{\pi z}{h}
\end{aligned}
$$

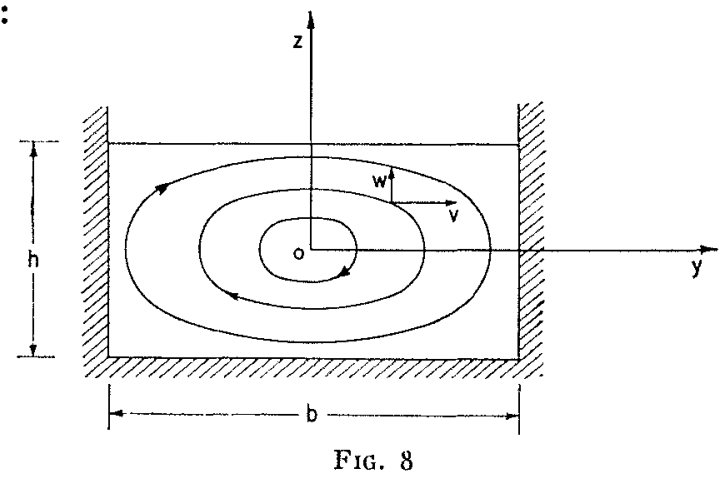


La valeur maximum de la vitesse horizontale est donnée par :
The maximum value of the horizontal velocity is given by :

$$
\left|v^{\star}\right|=\frac{k}{h} v_{c}
$$

et :

and :

$$
v_{c}=\bar{u} \frac{h}{k} \operatorname{tg} \varphi_{m}
$$

La vorticité est donnée à un point quelconque par l'expression :

The vorticity at any point is given by :

$$
\omega=\frac{4 \pi v_{b}}{k} \cos \frac{\pi y}{b} \cos \frac{\pi z}{h}
$$

Il en résulte que :

and hence :

$$
\begin{aligned}
\bar{\omega} & =\frac{16 v_{c}}{\pi k} \\
& =\frac{16 \bar{u} h}{\pi k^{2}} \operatorname{tg} \varphi_{m}
\end{aligned}
$$

Or, pour plusieurs raisons (en particulier, parce que les guideaux de fond « travaillent» dans une région d'écoulement retardé et parce qu'il n'y a pas de guides de surface) :
Now, for several reasons (in particular, because the bottom guides "work" in a region of retarded flow and because there are no surface guides) :

$$
\varphi \not \varphi_{m}
$$

Des essais ont montré que, pour des guides bien dessinés du type considéré ici :

Tests have shown that for properly designed guides of the type considered here :

$$
\operatorname{tg} \varphi_{m}=1,6 \frac{h^{\star}}{h}\left\{1--\frac{h^{\star}}{h}\right\} \operatorname{tg} \varphi
$$

approximativement.

La formule recherchée est donc la suivante:

$$
\bar{\omega}=\frac{25 \bar{u} h^{\star}}{\pi k^{2}}\left\{1-\frac{h^{*}}{h}\right\} \operatorname{tg} \uparrow
$$

Reste à examiner l'amortissement de la vorticité artificielle. Des essais ont montré qu'on peut appliquer la formule :
The damping out of the artificially induced vorticity remains to be considered. Tests have shown that the formula

$$
\left(v_{c}\right)_{x}=\left(v_{c}\right)_{0} e^{-\gamma x}
$$

avec .

is applicable, with :

$$
\gamma=\frac{4 \pi^{2} y^{*}}{k^{2} \bar{u}}
$$

où :

and :

$$
v^{\star}=\frac{g h \sqrt{h \mathrm{~T}}}{45}
$$

Les expressions (29) et (30) peuvent être déduites par une analyse théorique; toutefois, la
The formulae (29) and (30) can be derived theoretically; however, the kinematic viscosity $v^{*}$ 
viscositẻ cinématique apparente ${ }^{\star}{ }^{*}$ s'avère quelques centaines de fois supérieure à la viscosité cinématique réelle du fluide, pour peu que l'écoulement soit turbulent. Des essais effectués entre autres par VAGABOr conduisent à la formule $(31)^{*}$.

Il résulte de la définition de $\omega$ que la vorticité est régie par la même loi d'amortissement que $v_{c}$.

D) Analyse de L'Écoultament Secondaire CRéÉ DANS UN GHFNAL RECTILIGNE DIVERGENT PAR LES GUIDEAUX.

Le traitement qui suit est basé sur les travaux de Bolsharov. D'après l'équation (29), on peut écrire : is some hundreds of times greater than the real kinematic viscosity of the liquid, in turbulent flow, and tests by VAGABOV and others have led to the empirical $(31){ }^{*}$.

It follows from the definition of $\omega$ that the vorticity obeys the same law of damping as $v_{c}$.

\section{(D) ANalysis of SPIRal Flow In STRaigh't Diverg- ING CHANNELS WITII GUIDES.}

The following treatment is based on the work of Bolshakov.

Úsing equation (29), we may write :

Ici, $\gamma^{\star}$ est donné par $(30)$, avec :

$$
\frac{d v_{r}}{v_{c}}=-\gamma^{*} d x
$$

$$
k^{2}=\frac{4 b_{x}^{2} h^{2}}{b_{x^{2}}+h^{2}}=\frac{4 h^{2}\left(b_{1}+f x\right)^{2}}{\left(b_{1}+f x\right)^{2}+h^{2}}
$$

(on suppose que le chenal s'élargit sans s'approfondir).

D'autre part, dans l'équation (30): on the supposition that the canal widens without deepening.

$$
u_{0}=\frac{Q}{h\left(b_{1}+f x\right)}
$$

De (30), (33) et (34), il ressort que: $\quad$ From (30), (33), and (34) it follows that :

$$
\gamma^{*}=\frac{\pi^{2} v^{*}}{Q}\left\{\frac{\left(b_{1}+f x\right)^{2}+h^{2}}{h\left(b_{1}+f x\right)}\right\}
$$

Après intégration de (32), avec cette yaleur de $\gamma^{*}$, on obtient que :

Substituting in (32), we find after integration that :

$$
\ln \frac{\left(v_{c}\right)_{x}}{\left(v_{c}\right)_{0}}=-\frac{\pi^{2} v^{*}}{h f Q}\left\{h^{2} \ln \left(1+\frac{f x}{b_{1}}\right)+f x\left(b_{1}+\frac{f x}{2}\right)\right\}
$$

Certaines expériences effectuées sur les écoulements divergents tendent à montrer que la valeur de $v^{*}$ s'appliquant ici, peut être notablement plus élevée que celle fournie par l'expression (31). Ici, cependant, l'angle de divergence est sans doute suffisamment faible pour que cela puisse être négligé.

Enfin, on peut faire remarquer que, dans le canal d'amenée que nous considérons ici, la divergence n'est pas uniforme; très faible près du début du coude, elle augmente vers la rangée aval de guideaux. Par conséquent, $f$ n'est pas constant, et nous tiendrons compte de ce fait dans les calculs.

\footnotetext{
* Note de I’auteur. - Cet article était sous presse lorsque celui de M. Fontwer consacré aux écoulements giratoires dans les tuyaux circulaires parut dans $l a$ Houille Blanche, $\mathrm{N}^{\circ} \mathrm{B}, \mathbf{1 9 5 4}$.

Une comparaison des formules pour l'amortissement montre que les écoulements secondaires doivent en fait s'éteindre beaucoup plus rapidement dans les tuyaux ou canaux rectangulaires que dans les conduites circulaires.
}

Experiments on diverging flow nave shown that the value of $v^{*}$ to be used here may be considerably greater than that given by equation (31). In the present case, however, the divergence is perhaps sufficiently gradual for this to be negligible.

In conclusion, another point needs some attention. In the headrace canal considered here, the rate of divergence is very small near the first cascade, and increase as we near the second; $f$ is not constant. An allowance for this has been made in the subsequent calculations.

\footnotetext{
* AUthor's Note,-This article was in print when M. Fortier's article on the damping of swirling motion in pipes appeared in la Houille Blanche, $\mathrm{N}^{\circ} \mathrm{B}, 1954$.

A brief comparison shows that secondary currents in rectangular pipes or canals-our case-must die away much more rapidly than those in circular pipes.
} 


\section{E) ANalyse de L'ÉCOUlement TeCondatrJe CRÉÉ DANS UN CHENAL COURBE DIVERGENT PAR LES GUIDEAUX.}

Des essais ont montré que les vitesses axiales dans un écoulement ayant subi l'influence des guideaux sont à peu près uniformes sur toute la profondeur de courant (voir la figure 9 qui présente quelques résultats expérimentaux mentionnés par M. Bolshakov).

Il est légitime de supposer qu'aucun « eflet de HAWthorne 》 n'est à craindre dans ce cas;

\section{(E) Analysis of vorticity in Curved diverging CHANNELS WITH GUIDES.}

Tests have shown that the forward velocities in spiral flow induced by guides are almost uniform over the whole depth of flow; see fig. 9 which gives some typical experimental results referred to by Bolshakov.

No "Hawthorne effect" is therefore to be expected in this case, and the formulae derived

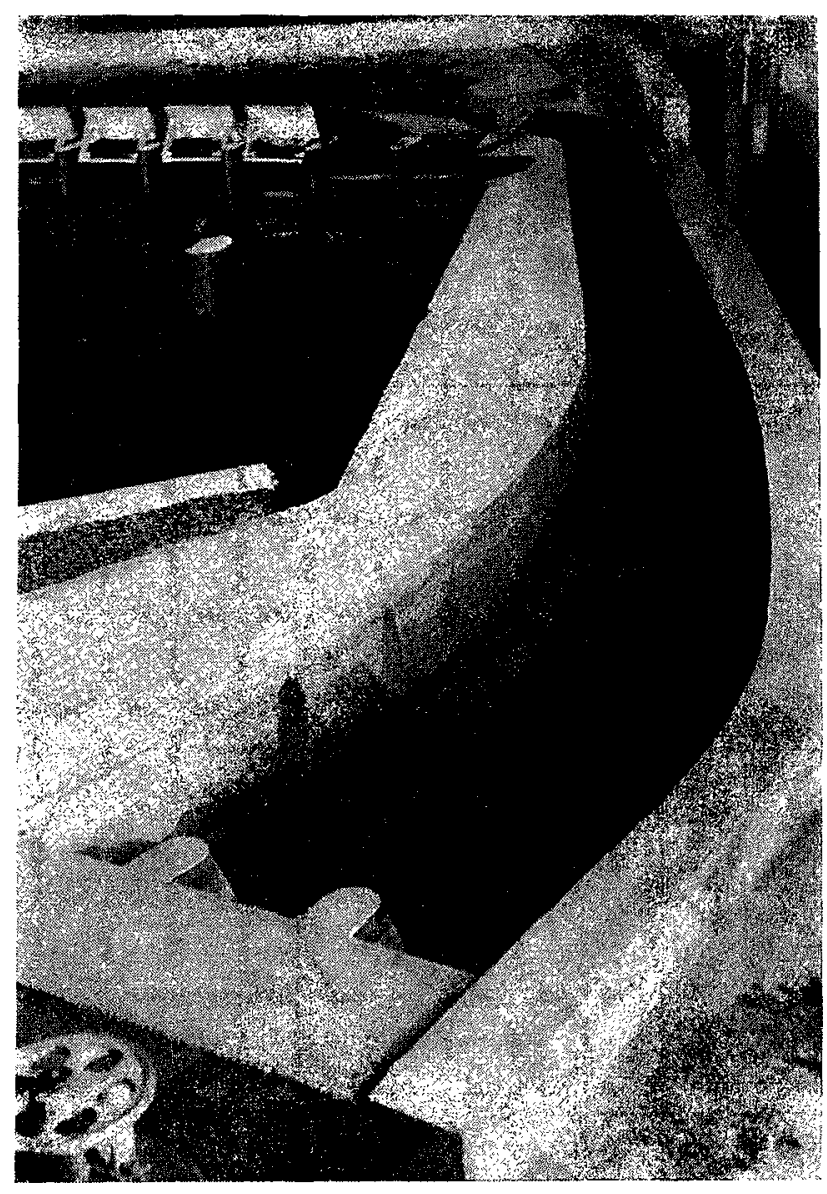

FIG. 9

les formules obtenues au $\$ D$ pourront donc être employées comme si le chenal était rectiligne. II est bien entendu toutefois qu'une répartition non uniforme de vitesses se développera si la circulation transversale «artificielle » vient à s'éteindre.

\section{APPLICATION DE LA THEORIE}

Dans la partie finale de cet article, on fera une application de la théorie précédente au canal in section $\mathrm{D}$ can be applied directly as though the canal were straight. It is true of course that a non-uniform velocity distribution will develop if the artificially induced, spiral flow is damped out.

\section{APPLICATION OF THE THEORY}

In the concluding part of this article the foregoing theory will be applied to the power canal 
d'amenée illustré par les figures 1 et 2 . Le niveau de la retenue admis dans notre étude sera de 438,50 et le débit de $120 \mathrm{~m}^{3} / \mathrm{sec}$.

$1^{\circ}$ Le développement de la vorticité naturelle dans la moitié R.G. du chenal.

En se référant à la figure 1 et à l'équation (22), nous trouvons :

a) De la section 00 à la section 11 : illustrated in figures 1 and 2 . The reservoir level will be taken as $438.50 \mathrm{~m}$ and the discharge $\mathrm{Q}=120 \mathrm{~m}^{3} / \mathrm{sec}$.

(1) The development of " natural" vorticity in the left-hand section of the canal.

Referring to fig. 1 and eqn. (22), we find that,

(i) From section 00 to section 11 :

$$
\int_{0}^{\theta} \bar{u} d \theta=0,3 \mathrm{~m} / \mathrm{sec}
$$

b) De la section 00 à la section 22 :

(ii) From section 00 to section 22 :

$$
\int_{0}^{0} \bar{u} d \theta=0,6 \mathrm{~m} / \mathrm{sec}
$$

Suivant les indications de M. Lipatov (voir l'ouvrage auquel M. Bolshakov a collaboré), nous admettrons que :

In accordance with the suggestions of Lipa'rov writing in the same volume as Bolshakov, we shall take (with a definition of $\beta$ that differs slightly from LipaTov's) :

$$
\beta=\frac{20}{C+4}
$$

Il mérite d'être mentionné que M. BAzIN (voir les Annales des Ponts et Chaussées, 1875, p. 309 et suivantes) donna des valeurs de $\beta$ un peu inférieures; pour une définition de la vitesse « de fond $\gg, u_{0}$, qui figure dans la définition de $\beta$ et qui a été employée par Lipatov, on se reportera à l'article de BAzrN.

Il résulte de ce qui précède que, à la section 11 :

$$
\bar{\omega}=-10^{-2} \sec ^{-1}
$$

et à la section 22, dans la nature également :

and, at section 22 :

$$
\bar{\omega}=-2 \times 10^{-2} \mathrm{sec}^{-1}
$$

Afin d'obtenir ces résultats, le chenal trapézoïdal réel a été assimilé à un chenal rectangulaire équivalent. Sur le modèle réduit, on aura des chiffres légèrement différents.

$2^{\circ}$ La création et l'amortissement de la circulation secondaire créés dans la moitié R.D. du chenal par les guideaux.

D'une application de l'équation (28), il ressort que la vorticité engendrée primitivement par la première rangée de trois guideaux s'élève à $5 \times 10^{-2} \mathrm{sec}^{-1}$ environ.

La loi d'amortissement (35) montre que, dans la nature, la vorticité «artificielle» sera ramenée à environ $3,5 \times 10^{-2} \mathrm{sec}^{-1}$ dans la section 11 où la seconde rangée de guideaux commence à agir. Sur le modèle, l'amortissement est légèrement supérieur; la vorticité dans la section 11 ne sera que de $2,5 \times 10^{-2} \mathrm{sec}^{-1}$ environ.
In order to obtain these results, the slightly trapezoidal canal has been replaced by an equivalent rectangular cross-section. On the model, slightly different figures apply.

(2) The production and decay of the vorticity artificially induced in the right-hand section of the canal.

An application of equation (28) shows that the vorticity originally created by the first cascade of three guides is equal to $5 \times 10^{-2} \mathrm{sec}^{-1}$ approximately.

The law of damping (35) shows that on the full scale, the vorticity will be reduced to about $3,5 \times 10^{-2} \mathrm{sec}^{-1}$ at section 11 , where the second cascade comes into play. On the model the damping is somewhat greater and a figure of about $2,5 \times 10^{-2} \mathrm{sec}^{-1}$ is reached. 
La seconde rangée crée une vorticité de l'ordre de 3 à $3,5 \times 10^{-2} \mathrm{sec}^{-1}$, vorticité qui ne s'ajoute pas à la vorticité résiduelle considérée au paragraphe précédent. Cependant, malgré l'apparente inutilité de cette rangée de guideaux, il fut démontré que celle-ci joue un rôle important dans certains cas de fonctionnement partiel des turbines.

Les résultats précédents sont portés sur la figure 10 . On remarquera que la vorticité naturelle atteint la valeur de la vorticité artificielle à la section 33, c'est-à-dire à l'entrée des groupes.
The second cascade produces a vorticity of about 3 to $3,5 \times 10^{-2} \mathrm{sec}^{-1}$; this is not additive to the residual vorticity considered in the preceding paragraph. However despite the apparent superfluousness of this cascade in the case considered, it was proved that its presence was necessary in order to ensure correct functioning of the forebay in certain cases of part operation of the turbines.

The foregoing results are plotted in fig. 10. It will be noted that the " natural" vorticity attains the value of the induced vorticity at section 33 , i.e., at the screens.

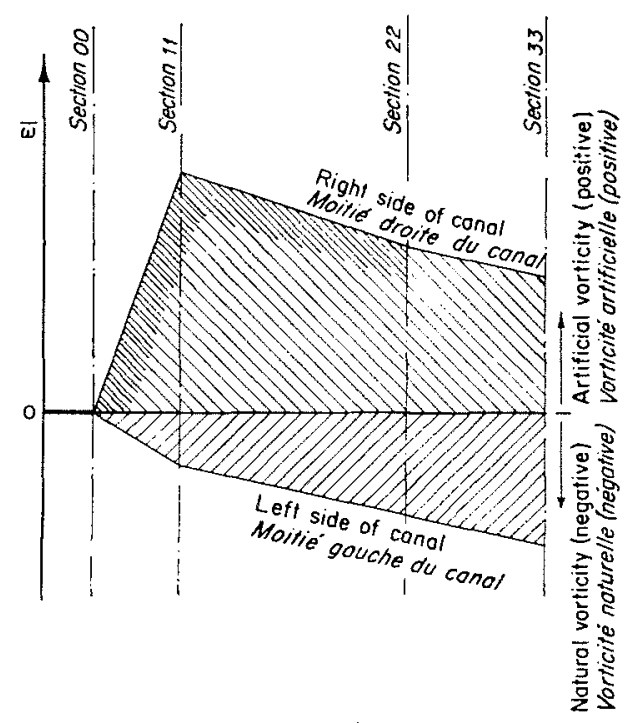

Fig. 10

Il convient de noter également que si, par exemple, le débit $Q$ et la vitesse $\bar{u}$ sont diminués sans que le niveau moyen soit modifié, les vorticités évaluées précédemment décroissent approximativement d'après la même loi de proportionnalité (le coefficient d'amortissement subit toutefois une augmentation). D'autre part, si le débit reste constant et que le niveau varie, cette même proportionnalité approximative est respectée. On peut donc affirmer que dans une gamme de conditions d'exploitation assez étendue, un même système de guideaux donnera toute satisfaction.

\section{CONCLUSION}

Une première conclusion relève d'une constatation faite sur le modèle réduit; il a été démontré que les guideaux doivent agir dès le début $\mathrm{du}$ coude. Bien qu'on ne puisse en fournir une explication purement théorique, on peut déduire, d'après l'analyse des effets produits par les gui-
It should be noted that if, for example, the discharge $Q$ and the velocity $\bar{u}$ are reduced without changing the mean waterlevel, the vorticities considered above are also reduced in approximately the same ratio the damping coefficient is however increased). On the other hand, if the discharge remains constant but the level varies, the same approximate law of proportion holds true. 'This shows that, within wide limits, a set of guides designed for one flow condition is likely to prove just as suitable for another, apparently quite different, flow condition in the same canal.

\section{CONCLUSION}

The first conclusion is that the guides must create a circulation countering the "natural" circulation right from the start of the bend. This is a practical test result, and is somewhat difficult to justify in theoretical grounds. However it may be inferred from the explanation of the 
deaux (voir la fig. 6) que, surtout dans un écoulement rapide, le transfert des filets rapides aux endroits «sensibles 》 de la paroi exige un parcours considérable; il en résulte que la vorticité engendrée par la première rangée de guideaux ne sera utile qu'assez loin en aval où, dans la moitié « libre »du chenal, la circulation secondaire «naturelle » s'avère déjà appréciable.

En second lieu, on peut déduire de l'analyse théorique de l'écoulement secondaire que, à l'extrémité aval du coude, la vorticité 《artificielle » créée dans une moitié du canal doit être approximativement égale à la vorticité « artificielle 》 (voir la fig. 10). Cette rigle approximative demande à être vérifiée par d'autres essais, et il est également possible que certaines hypothèses admises ici, soient à modifier ultérieurement.

Au point de vue pratique, toutefois, il est d'ores et déjà certain que le procédé décrit ici constitue une méthode particulièrement heureuse de résoudre un problème hydraulique épineux.

L'auteur désire exprimer ses remerciements à M. Ie Président de la Société des Forces HydroElectriques de l'Est de la Colonie, Bruxelles, pour l'autorisation accordée pour la publication de cet article.

Les études furent effectuées au cours des années 1951-1952. action of the guides (see fig. 6), that-especially in a fast current-the transfer of fast-moving water to critical points on the side wall will require a good distance, and that the vorticity created by the first cascade of guides will be operative only at some distance downstream where, in the "free" half of the channel, the "natural" circulation is already appreciable.

Secondly, it may be deduced from the theoretical treatment of secondary flow that the induced vorticity in the inner side of the channel should be approximately equal to the " natural " vorticity in the outer part of the channel at the end of the bend (see fig. 10). This approximate design rule needs to be verified by further experiment; it is also possible that certain of the assumptions made in the present theory may need modification.

From a purely practical point of view, however it is quite certain that the method described here constitutes a particularly successful method of solving a difficult hydraulic problem.

\section{AcKNowledgMent}

The author desires to express his appreciation of the permission granted him by the President of the Société des Forces Hydro-Electriques de l'Est 'de la Colonie to publish this article.

The work was carried out in 1951-1952.

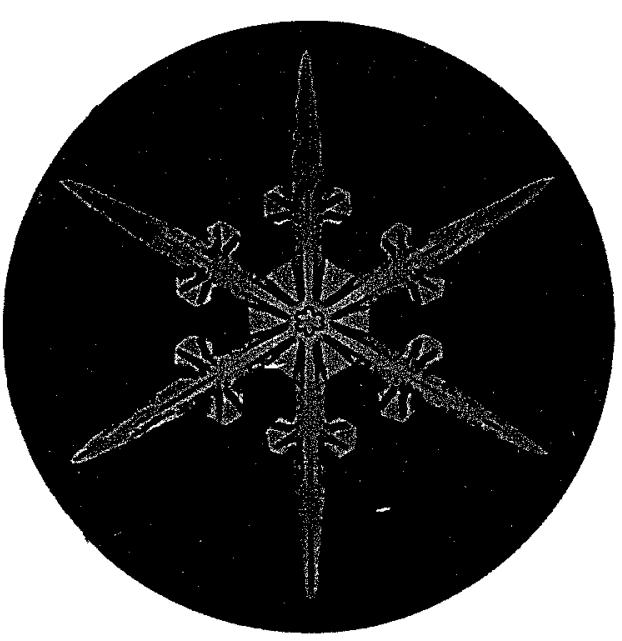

